\title{
BALANCE ON NASH IN "SOFT" CONTROL PROBLEMS FOR SYSTEMS OF THE HIERARCHAL TYPE
}

\author{
V.V. Menshikh ${ }^{1}$, D.E. Orlova ${ }^{2}$ \\ ${ }^{1}$ Voronezh Institute of the Ministry of Internal Affairs of Russia, Voronezh, \\ Russian Federation \\ ${ }^{2}$ Voronezh Institute of Federal Penitentiary Service, Voronezh, Russian Federation \\ E-mails: menshikh@list.ru, dashken10091991@gmail.com
}

\begin{abstract}
This paper discusses the hierarchical system, which includes the Center, symbolizing the global interests of the system and control objects $(\mathrm{CO})$, perform guidance Center, but at the same time pursuing its own local interests. In the first phase, the Centre produces a decision, taking into account global interests, and in the second stage $\mathrm{CO}$ chooses a specific version of the decision, taking into account their own administration and their local interests. It is anticipated that decision is consistent if the interests of each of the parties are counted so that a departure from it cannot improve the performance of any of the parties, i.e. it is balance on Nash. "Soft" control suggests that for each pair of "Center-facility control" global and local interests are taken into account in varying degrees. The method of finding equilibrium solutions depending on the extent of the accounting of interests and levels of reflection is found.
\end{abstract}

Keywords: "soft" control; hierarchical type system; Center; facility control; balance on Nash.

\section{Introduction}

An important circumstance accompanying the decision making in hierarchical systems is their two-stage [1]. In the first phase, the Centre produces a decision, taking into account global interests, and at the second stage of the control objects (CO) opt for a specific version of the decision, taking into account their own administration and their local interests (for example, preserving and enhancing its capacity).

The paper deals with the situation of "soft" control, according to which, depending on the conditions of the environment in which the system operates, the relationship between global and local interests can vary in a fairly wide range. So, in a critical (freelance) setting an absolute priority, as a rule, serves the global interests of the system, and local interests of $\mathrm{CO}$ go by the wayside. In situations where the Centre is losing control due to a number of circumstances, CO can focus exclusively on their own interests, ignoring global interests.

In the usual (regular) environment, the parties tend to seek sustainable compromise solutions, a departure from the implementation of which can't improve the efficiency of any of the parties [2]. Such solutions are called resilient or equilibrium, in the sense of Nash [3, 4]. The search for such solutions is usually based on parity of interests of the parties, regardless of the conditions of the situation, which does not cover those situations where the balance of interests of the parties may vary in different directions $[5,6]$.

In this regard, there is a need to find formal conditions that, being implemented in the control process in the organizational and technical systems of a hierarchical type, in themselves ensure the stability of control decisions in the conditions of "soft" control. 


\section{The Wording of the Problem}

Denote by $R=\left\{r_{1}, r_{2}, \ldots, r_{|R|}\right\}$ a set of many potential control decisions in the control system. Each control decision is formed on the basis of the following sets: $N=$ $\left\{n_{1}, n_{2}, \ldots, n_{|N|}\right\}$ is a set of many potential decisions of the control body; $L=\left\{l_{1}, l_{2}, \ldots, l_{|L|}\right\}$ is a set of potentially many possible solutions to the control body. Thus, $r_{i}=\left(n_{j}, l_{k}\right)$ and $R \subseteq N \times K$.

We will consider the given:

$-Q: R \rightarrow \operatorname{Re}$ is a set of functions characterizing the effectiveness of control decisions (wins) from the center's point of view (Re is set of integers);

$-q: R \rightarrow \operatorname{Re}$ is a set of functions characterizing the effectiveness of control decisions (wins) in terms of $\mathrm{CO}$;

$-f(Q, q): R \rightarrow$ Re is a set of complex functions, taking into account the interest of both sides.

It is natural to assume that this function is a linear combination of functions $Q$ and $q$, that is

$$
f(Q, q)=\nu \cdot Q(r)+(1-\nu) \cdot q(r) .
$$

\section{The Problem of Choosing Optimal Options for Control Decisions}

Will designate an optimal variant of $r^{*}=\left(n^{*}, l^{*}\right)$. The following situations are possible: 1 ) if only takes into consideration global interests center, then $r^{*}=\left(n^{*}, l^{*}\right)$ must meet the condition

$$
\forall n \forall l \quad Q\left(n^{*}, l^{*}\right) \geq Q(n, l) ;
$$

2) if only the local CO, then $r^{*}=\left(n^{*}, l^{*}\right)$ must meet the condition

$$
\forall n \forall l \quad q\left(n^{*}, l^{*}\right) \geq q(n, l) ;
$$

$3)$ if equally taken into account the global interests of the Centre and the local interests of $\mathrm{CO}$, then $r^{*}=\left(n^{*}, l^{*}\right)$ must meet the conditions of Nash equilibrium

$$
\begin{cases}\forall l & Q\left(n^{*}, l^{*}\right) \geq Q\left(n^{*}, l\right) ; \\ \forall n & q\left(n^{*}, l^{*}\right) \geq q\left(n, l^{*}\right) .\end{cases}
$$

Unfortunately, the Nash equilibrium has a significant drawback. It may not be the only one. In this case, you need some mechanism, allowing you to delete multiple options. In the present case, such an instrument could become a distinction of ranks reflection players. Let $K$ is a center reflection rank, $k$ is a the rank of reflection of CO.

If it should be taken into account to a greater extent the interests of central, then $R=$ $0, r=1$ and should maximize its payoff. In this case, the Nash equilibrium $r^{*}=\left(n^{*}, l^{*}\right)$ is found as a solution to the problem

$$
r^{*}=\left(n^{*}, l^{*}\right)=\operatorname{Arg} \max Q\left(n^{*}, l^{*}\right),
$$

satisfying the system of inequalities (3).

If it should be taken into account to a greater extent the interests of $\mathrm{CO}$, then $K=1$, $k=0$ and should maximize its payoff. In this case, Nash equilibrium $r^{*}=\left(n^{*}, l^{*}\right)$ is

$$
r^{*}=\left(n^{*}, l^{*}\right)=\operatorname{Arg} \max q\left(n^{*}, l^{*}\right),
$$

satisfying system of inequalities (3). 


\section{The Situation that Occurs when the Control is "Soft"}

Let us now consider situations where it is necessary to take into account the interests of the parties to varying degrees. To do this, all the situations that arise in the process of system control, will be divided into two classes:

a) situations where collective decisions when choosing appropriate to focus on the global interests of the Centre and to a lesser extent, take into account the local interests of $\mathrm{CO}$;

b) situations where collective decisions when choosing appropriate proceed from local interests of $\mathrm{CO}$, but take into account the global interests of the Center.

If evaluate the parameter $\nu=[0,1]$ a situation where one of the parties may, to some extent, function in the interests of the opposite party up to the complete disregard of its own interests $(\nu=1)$.

If the CO is partially or fully operational for the centre, then instead of the system of inequalities (3) consider the system of

$$
\begin{cases}\forall l & Q\left(n^{*}, l^{*}\right) \geq Q\left(n^{*}, l\right) ; \\ \forall n & Q\left(n^{*}, l^{*}\right)+(1-\nu) q\left(n^{*}, l^{*}\right) \geq \nu Q\left(n, l^{*}\right)+(1-\nu) q\left(n, l^{*}\right) .\end{cases}
$$

In this case, the solution of the problem of finding Nash equilibrium $r^{*}=\left(n^{*}, l^{*}\right)$ is problem (4), (6).

Indeed, if $\nu=0$ this problem is reduced to problem (4), (3). Show that if $\nu=1$, the solution to this problem is equivalent to running condition (1). In substitution in (6) $\nu=1$ the system of inequalities (6) turns into a system

$$
\begin{cases}\forall l & Q\left(n^{*}, l^{*}\right) \geq Q\left(n^{*}, l\right) ; \\ \forall n & Q\left(n^{*}, l^{*}\right) \geq Q\left(n, l^{*}\right) .\end{cases}
$$

Obviously, if $r^{*}=\left(n^{*}, l^{*}\right)$ satisfies condition (1), that it satisfies both of system (7), determining weaker conditions. However, in accordance with (4) $Q\left(n^{*}, l^{*}\right)$ should be the maximum among all possible solutions of system (7). Therefore, it coincides with one of solutions (1). If the Centre operates partially or totally for CO, instead of a system of inequalities (3) consider the system of

$$
\begin{cases}\forall l & (1-\nu) Q\left(n^{*}, l^{*}\right)+\nu q\left(n^{*}, l^{*}\right) \geq(1-\nu) Q\left(n^{*}, l\right)+\nu q\left(n^{*}, l\right) ; \\ \forall n & q\left(n^{*}, l^{*}\right) \geq q\left(n, l^{*}\right) .\end{cases}
$$

In this case, the problem of finding Nash equilibrium $r^{*}=\left(n^{*}, l^{*}\right)$ is found as a solution to problem (5), (8). Indeed, if $\nu=0$, this problem is reduced to problem (5), (3). Show that if $\nu=1$ the solution to this problem is equivalent to running condition (1).

When substituting in (8) $\nu=1$ system of inequalities (8) turns into system

$$
\begin{cases}\forall l & q\left(n^{*}, l^{*}\right) \geq q\left(n^{*}, l\right) \\ \forall n & q\left(n^{*}, l^{*}\right) \geq q\left(n, l^{*}\right)\end{cases}
$$

Obviously, if $r^{*}=\left(n^{*}, l^{*}\right)$ satisfies condition (2), that it satisfies both of system (9), determining weaker conditions. However, in accordance with $(5) q\left(n^{*}, l^{*}\right)$ should be the maximum among all possible solutions of system (9). Therefore, it coincides with one of solutions (1). 


\section{Algorithm for Finding Solutions}

The above considerations allow to develop an algorithm for finding sustainable compromise solutions in the "soft" control in organizational and technical systems of the hierarchical type. The essence of it is in the next:

Step 1. Form the source data: define multiple

$$
R=\left\{r_{1}, r_{2}, \ldots, r_{|R|}\right\}, N=\left\{n_{1}, n_{2}, \ldots, n_{|N|}\right\}, L=\left\{l_{1}, l_{2}, \ldots, l_{|L|}\right\}
$$

set function $Q$ and $q$.

Step 2. Set the class of the control situation: a) or b).

Step 3. The expert method, determine the value of the coefficient of

$$
\nu=[\overline{0,1}] .
$$

Step 4. Solve problem (4), (6) (for situation 1) or problem (5), (8) (for situation 2) define $r^{*}=\left(n^{*}, l^{*}\right)$.

Step 5. If the set of these solutions is not empty, then we carry out the output of the results, the algorithm is completed. Otherwise, go to step 1 to adjust the original data.

\section{A Numerical Example}

Consider the choice decision if many potential solutions Center

$$
N=\left\{n_{1}, n_{2}, n_{3}\right\}
$$

control object

$$
L=\left\{l_{1}, l_{2}, l_{3}, l_{4}\right\}
$$

We assume that many potential managerial decisions in the system of control $R \subseteq N \times L$ include the following elements:

$$
r_{1}=\left(n_{1}, l_{1}\right), r_{2}=\left(n_{1}, l_{2}\right), r_{3}=\left(n_{2}, l_{1}\right), r_{4}=\left(n_{2}, l_{3}\right), r_{5}=\left(n_{3}, l_{3}\right), r_{6}=\left(n_{3}, l_{4}\right) ;
$$

- function efficiency of managerial decisions in terms of the Center

$$
Q(R)=(20,16,14,10,8,4) ;
$$

- function efficiency of managerial decisions in terms of control object

$$
q(R)=(3,15,7,11,15,17)
$$

If only takes into consideration global interests, the centre, as it can be seen from formula (1)

$$
r^{*}=r_{1},
$$

and if only takes into consideration global interests of control object, as can be seen from formula (2)

$$
r^{*}=r_{6} .
$$

If we take into account both global and local interests, there are solutions that meet condition (3) Nash equilibrium. The analysis shows that there are two such solutions: 


$$
\begin{aligned}
& r^{*}=r_{3}, \quad \text { since } Q\left(n_{2}, l_{1}\right) \geq Q\left(n_{2}, l_{3}\right) ; q\left(n_{2}, l_{1}\right) \geq q\left(n_{1}, l_{1}\right) ; \\
& r^{*}=r_{5}, \text { since } Q\left(n_{3}, l_{1}\right) \geq Q\left(n_{3}, l_{4}\right) ; q\left(n_{3}, l_{3}\right) \geq q\left(n_{2}, l_{3}\right) .
\end{aligned}
$$

If a greater degree of interests are taken into account, i.e. the rank of the reflection of the control object anymore, then in accordance with (4) it should be chosen the solution

$$
r^{*}=r_{3}, \text { since } Q\left(n_{2}, l_{1}\right) \geq Q\left(n_{3}, l_{3}\right) .
$$

If it is taken into account to a greater extent the interests of control object, since the rank reflection Center more in keeping with (5) the solution

$$
r^{*}=r_{5}, \quad \text { since } q\left(n_{3}, l_{3}\right) \geq q\left(n_{2}, l_{1}\right)
$$

\section{Conclusion}

The proposed method finds sustainable compromises when managing the logistical systems of a hierarchical type which is different from the classical model of Nash equilibrium that is supplemented by conditions that reflect the nature of the situation decision-making and the ratio of global and local interests of the parties. This addition is done by introducing a special function that characterizes a tendency of parties to compromise. This method and the algorithm can find practical application as a decision support tool in the control of complex dynamic systems of technical-organizational type in which the human factor plays a significant role.

\section{References}

1. Mesarovic M., Mako D., Takahara I. Teoriya ierarhicheskih i mnogourovnevyh sistem [Theory of Hierarchical and Multilevel Systems]. Moscow, Mir, 1973. (in Russian)

2. Menshikh T.V. Ispol'zovanie igr s ierarhicheskim vektorom interesov dlya resheniya zadach obespecheniya informacionnoy bezopasnosti [The Use of Games with a Hierarchical Vector of Interests for Solving Problems of Information Security]. Ohrana, bezopasnost, svyaz, 2017, no. 1, pp. 82-86. (in Russian)

3. Germeyer Yu.B. Igry s neprotivopolozhnymi interesami [Games with Non-Opposing Interests]. Moscow, Nauka, 1976. (in Russian)

4. Menshikh T.V. Estimation of Parameters of Games with a Hierarchcal Vector of Interests. Bulletin of the South Ural State University. Series: Mathematical Modelling, Programming and Computer Software, 2018, vol. 11, no. 3, pp. 118-122. DOI: 10.14529/mmp180309 (in Russian)

5. Germeyer Yu.B., Vatel I.A. Games with a Hierarchical Interest Vector. Tekhnicheskaya Kombinatorika, 1974, no. 3, pp. 54-69. (in Russian)

6. Orlova D.E. Sustainability Solutions, While Ensuring the Functioning of the OrganizationalTechnical Systems. Modeling, Optimization and Information Technology, 2018, vol. 6, no. 1, pp. 325-336. (in Russian)

Received August 14, 2018 
УДК 519.83

DOI: $10.14529 / \mathrm{mmp} 190113$

\title{
РАВНОВЕСИЕ ПО НЭШУ В ЗАДАЧАХ «МЯГКОГО УПРАВЛЕНИЯ В СИСТЕМАХ ИЕРАРХИЧЕСКОГО ТИПА
}

\author{
В.В. Менъиих ${ }^{1}$, Д.Е. Орлова \\ ${ }^{1}$ Воронежский институт МВД России, г. Воронеж, Российская Федерация \\ ${ }^{2}$ Воронежский институт ФСИН России, г. Воронеж, Российская Федерация
}

\begin{abstract}
Рассматривается иерархическая система, включающая центр, олицетворяющий глобальные интересы системы, и объекты управления (ОУ), выполняющие указания Центра, но одновременно преследующие и собственные локальные интересы. На первом этапе Центр формирует решение, учитывая глобальные интересы, а на втором этапе ОУ выбирают конкретный вариант исполнения этого решения, учитывая собственные возможности по его исполнению и свои локальные интересы. Предполагается, что решение устойчиво, если учтены интересы каждой из сторон так, что отход от него не может повысить эффективность функционирования ни одной из сторон, т.е. оно является равновесием по Нэшу. «Мягкое» управление предполагает, что для каждой пары «центр-объект управления» глобальные и локальные интересы учитываются в разной степени. Найден метод нахождения равновесного решения в зависимости от степени учета интересов и ранга рефлексии.
\end{abstract}

Ключевые слова: «мягкое» управление; системы иерархического типа; иентр; объект управления; равновесие по Нэшу.

\section{Литература}

1. Месарович, М. Теория иерархических и многоуровневых систем / М. Месарович, Д. Мако, И. Такахара. - М.: Мир, 1973.

2. Меньших, Т.В. Использование игр с иерархическим вектором интересов для решения задач обеспечения информационной безопасности / Т.В. Меньших // Охрана, безопасность, связь. - 2017. - № 1. - С. 82-86.

3. Гермейер, Ю.Б. Игры с непротивоположными интересами / Ю.Б. Гермейер. - М.: Наука, 1976.

4. Меньших, Т.В. Оценка параметров игр с иерархическим вектором интересов Т.В. Меньших // Вестник ЮУрГУ. Серия: Математическое моделирование и программирование. - 2018. - Т. 11, № 3. - С. 118-122.

5. Гермейер, Ю.Б. Игры с иерархическим вектором интересов / Ю.Б. Гермейер, И.А. Ватель // Техническая комбинаторика. - 1974. - № 3. - С. 54-69.

6. Орлова, Д.Е. Устойчивость решений при обеспечении функционирования организационно-технических систем / Д.Е. Орлова // Моделирование, оптимизация и информационные технологии. - 2018. - Т. 6, № 1. - С. 325-336.

Валерий Владимирович Меньших, доктор физико-математических наук, професcop, кафедра «Математика», Воронежский институт МВД России (г. Воронеж, Российская Федерация), menshikh@list.ru.

Дарья Евгеньевна Орлова, адъюнкт, Воронежский институт ФСИН России (г. Воронеж, Российская Федерация), dashken10091991@gmail.com.

Поступила в редакиию 14 августа 2018 г.

Вестник ЮУрГУ. Серия «Математическое моделирование

и программирование» (Вестник ЮУрГУ ММП). 2019. Т. 12, № 1. С. 144-149 